\title{
Cathepsin Antibody Measurement
}

National Cancer Institute

\section{Source}

National Cancer Institute. Cathepsin Antibody Measurement. NCI Thesaurus. Code C120634.

The determination of the cathepsin antibody present in a sample. 